\section{Seasonal variations in monoterpene profiles and ecophysiological traits in Mediterranean pine species of group "halepensis"}

\author{
Michelozzi M, Tognetti R, Maggino F, Radicati M
}

Abstract: Foliar and cortical terpene profile, and needle gas exchange and water potential of $P$. halepensis, $P$. brutia and $P$. eldarica were compared over three consecutive seasons (1996-1998) in an experimental plantation nearby Firenze (Italy). Terpene percentages in mature tissue (cortex and needle) did not change in response to water stress during summer period and remained stable through seasons and years. Terpene profiles were not affected by seasonal drought, and are thus valuable to characterize Mediterranean pine species of the group "halepensis". There was a threshold-type response of maximum daily gas exchange to decreasing predawn water potential in all pines. Net photosynthesis and needle conductance were linearly related, regardless of the species.

Keywords: Pinus halepensis, terpene, drought, photosynthesis, water relations

\section{Introduction}

Pinus halepensis Mill. is a circum-Mediterranean species, mainly present in southern Europe and North Africa, but also in the Middle East. Pinus brutia Ten. has a rather restricted distribution, limited to the eastern Mediterranean region of Kurdistan mountains. Pinus eldarica Medw. occurs in natural stands in Transcaucasus region, but also in Iran, Afghanistan and Pakistan. Within Mediterranean-type ecosystems (Weinstein 1989), this group of species is ecologically important for its resilience to fire and has economical importance for timber and oleoresin.

Oleoresin is a mixture of different classes of terpenoids (monoterpenoids, sesquiterpenoids and diterpenoids) and phenolics. Terpenes play a fundamental role in defence chemistry of the plant; terpenoid mixtures in conifer trees are constitutive (primary resin or pre-formed resin) and induced or newly synthesised in response to attack by herbivores and microbes (secondary resin) (Langenheim 1994, Raffa \& Smalley 1995, Cates

(1)Istituto di Genetica Vegetale - CNR, Firenze, Italy; ${ }^{(2)}$ Dipartimento di Scienze Animali, Vegetali e dell'Ambiente, Università degli Studi del Molise, Campobasso, Italy; ${ }^{(3)}$ Dipartimento di Studi Sociali, Università degli Studi di Firenze, Italy.

${ }^{*}$ Corresponding Author: Marco Michelozzi (marco.michelozzi@igv.cnr.it).

Citation: Michelozzi M, Tognetti R, Maggino $\mathrm{F}$, Radicati M, 2008. Seasonal variations in monoterpene profiles and ecophysiological traits in Mediterranean pine species of group "halepensis". iForest 1: 65-74 [online: Feb 28, 2008] URL: http://www.sisef.it/iforest/
1996). The relative proportions (percentages) of constitutive monoterpenes in mature tissues are under strong genetic control and are little affected by environmental parameters (Baradat et al. 1991, Hanover 1992, Plomion et al. 1996). Therefore, monoterpenes have found applications in forest genetics as biochemical markers in chemotaxonomy and in selecting less susceptible chemotypes to pests and diseases (Baradat et al. 1991, Hanover 1992, Michelozzi et al. 1995, Michelozzi 1999). During periods of water stress, low soil moisture lowers water potential; when atmospheric humidity is limiting, declining stomatal conductance is associated with decreasing net photosynthesis. Because of the close correlations between changes in stomatal conductance and net photosynthesis, it may be assumed that limiting diffusion of $\mathrm{CO}_{2}$ into leaves may alter carbon physiology of these species.

Previous studies showed that genetic variability in P. halepensis, P. brutia, and P. eldarica could be characterized by the analysis of monoterpene profiles (Baradat et al. 1995, Schiller \& Grunwald 1987a, b, Michelozzi et al. 1990). However no studies were performed to investigate seasonal effects in terpene levels in these Mediterranean pine species. Besides, there is little comparative information on the ecophysiological response of $P$. halepensis, $P$. brutia and P. eldarica to site environmental condition.

The objectives of this study were: 1) to determine the seasonal effect on relative proportions (percentages) of constitutive monoterpenes in mature foliar and cortical tissues; 2) to investigate species-specific patterns of ecophysiological characters during the whole year in these Mediterranean pines;
3) to verify the degree of coupling between environment-induced changes (if any) in terpene percentages and seasonal trends in foliage functions (needle gas exchange and water potential) of the "halepensis" group. The results of this study will provide information that may be used in breeding programs for better resin quality and resistance to abiotic and biotic stresses. Species of the $P$. halepensis group are ecologically classified as drought tolerant enduring strong water stress conditions. Nevertheless, the predicted rise in mean temperature, erratic rainfall and evapotranspiration in the Mediterranean region as a result of global warming may have adverse effects on the long-term productivity of pine woodlands and on the interaction between organisms at ecosystem level.

\section{Materials and methods}

\section{Site location and plant material}

The study was conducted from May 1996 to February 1999 at an experimental plantation near Firenze (central Italy, lat. 43 78' N, long. 1132 ' E). The site is situated in a hilly area at an elevation of about $110 \mathrm{~m}$. The climate is typical Mediterranean, with cool, wet winters and hot, dry summers; climatic data were recorded by a nearby meteorological field station (Fig. 1). Mean annual temperature is $14.5 \mathrm{C}$ and mean annual rainfall 912 $\mathrm{mm}$. Soil at the experimental site is clayloam. The plantation, including Pinus halepensis Mill., P. brutia Ten. and P. eldarica Medw., was established in 1985. Mean tree height and breast height diameter (at the time of measurements) were about 10 $\mathrm{m}$ and $14 \mathrm{~cm}$, respectively.

\section{Terpene analysis}

One-year-old cortical and foliar tissue samples were taken from $P$. halepensis, $P$. brutia, and $P$. eldarica trees growing in the experimental plantation. Terpene composition was analysed by means of headspace gas chromatography using a Perkin-Elmer 8500 gas chromatograph equipped with a flame ionisation detector and with a PerkinElmer HS-101 automatic headspace sampler. A J\&J fused silica capillary column $30 \mathrm{~m} \mathrm{x}$ 0.25 coating DB-WAX was used. Peak area on the chromatograms was expressed as a percentage of the total monoterpenes taken into consideration $(\alpha$-pinene, camphene, $\beta$ pinene, sabinene, $\delta$ - 3 carene, $\beta$-myrcene, limonene, cineole, $\gamma$-terpinene); the sesquiterpene, $\beta$-caryophillene, was expressed as a percentage of total terpenes. The identification of compounds was made by comparison with the retention times of pure monoterpenes. Two peaks could not be identified and were named unknown 1 and 2, respectively. 


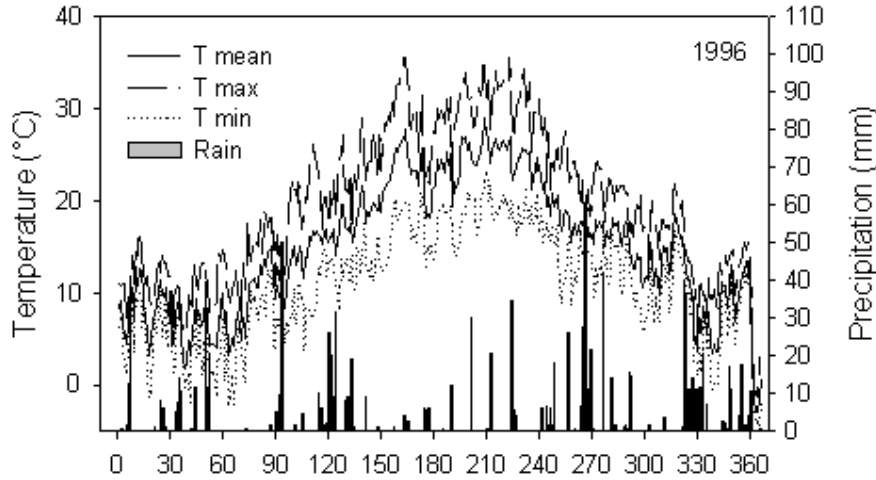

Day of year (Julian day)
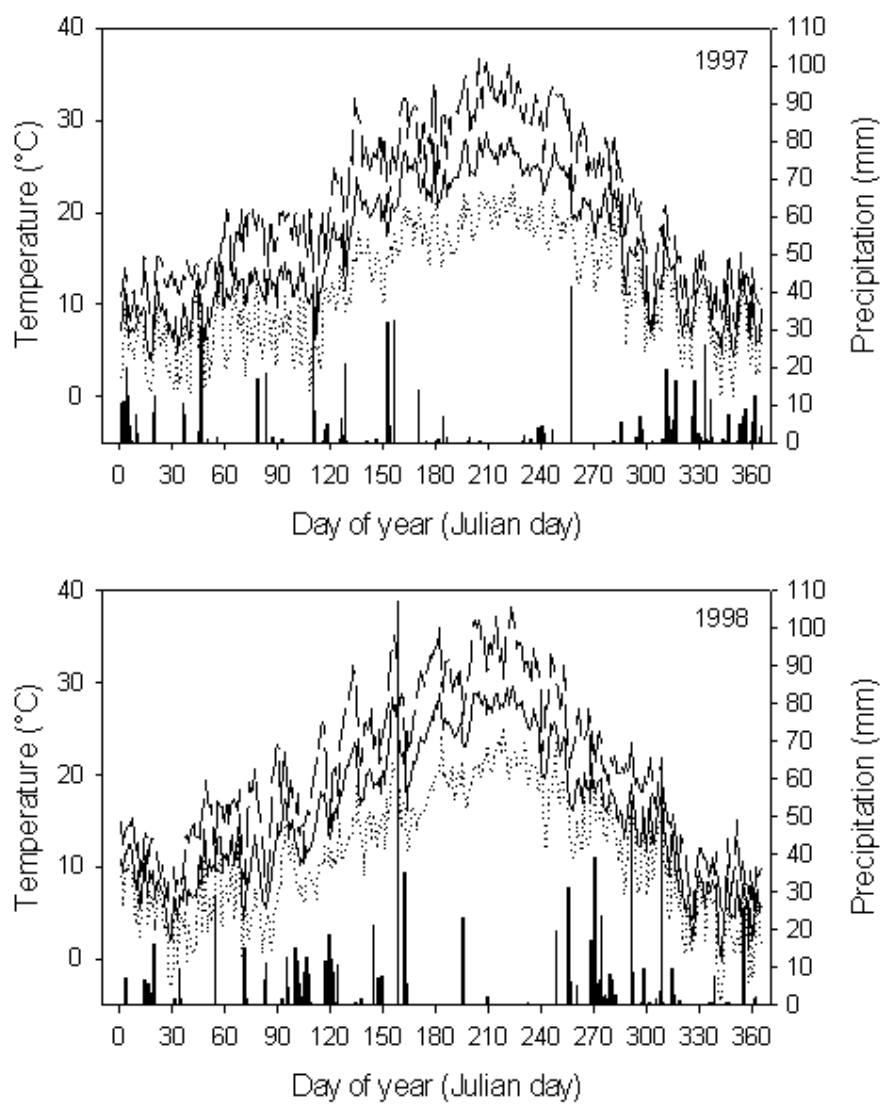

Fig. 1 - Seasonal course of monthly means of rainfall and temperatures during the study period at the experimental site.

\section{Physiological measurements}

Needle gas exchange measurements were made with a portable infrared gas analyser Ciras-1 (IRGA) (PP-Systems, Hitchin, Herts, UK) equipped with a conifer cuvette, between 1100 hours and 1400 hours, under ambient conditions on sunny days when irradiance was above saturation for photosynthesis. The following parameters were calculated: net photosynthetic rate $\left(A_{\mathrm{n}}\right)$ expressed on a needle area basis and stomatal conductance $\left(g_{s}\right)$, calculated by assuming zero air resistance in the boundary layer. Measurements of needle xylem pressure potential were made using a pressure chamber following techniques described by Ritchie \& Hinckley (1975). Measurements were made at about monthly interval during the growing season and periodically during the rest of the year. On several occasions, measurements of gas exchange and water potential were made between sunrise and solar noon on tagged shoots.

All measurements were made on 1-year- old foliage, in the upper one-third of the canopy on the second and third whorl of branches of six sample trees per species. Each measurement started with predawn xylem pressure potential $\left(\Psi_{\mathrm{pd}}\right)$ measured approximately $30 \mathrm{~min}$ before sunrise. on individual nearby fascicles of the same shoot or on comparable shoot tips (two to three on each branch). Means were made averaging the readings on trees for each measurement period.

Measurements of gas exchange were taken on two fully illuminated branches for each tree. The same branches, or nearby branches, were used throughout the study period. One or two fascicles of needles on each sample branch were arranged in the leaf chamber minimizing self-shading. Sample measurements were limited to $30 \mathrm{~s}$ to reduce variation between ambient and chamber environments. The foliage was then removed from the chamber for needle area determination following the method of Johnson (1984).

\section{Data analysis}

A variance analysis was performed on the arcsine transformed monoterpenes percentages. Seasonal course values were compared with a repeated measures analysis of variance, which takes into account both comparison between species and trends over time (Potvin et al. 1990, Castell \& Terradas 1994, Coli et al. 1997). The nonparametric test of Friedman was used to verify the results of repeated measures analysis of variance. Whenever necessary, this test was followed by mean comparison to determine when significant differences were obtained. The $t$ Test was used to evaluate differences in single monoterpenes between every pair of sampling dates. The relationships between $A$ $\mathrm{n}$ and $g_{\mathrm{s}}$ were compared by means of test of homogeneity of error and comparison between regression coefficients.

\section{Results}

Seasonal patterns of terpene profiles

There were minor seasonal effects on monoterpene profiles (Fig. 2 and Fig. 3). $\alpha$ pinene and myrcene were the most abundant constitutive monoterpenes in needle and cortical tissues of $P$. halepensis. $\beta$-pinene and $\alpha$-pinene were the main components in needles and cortex of $P$. brutia. $\alpha$-Pinene was the main monoterpene of foliar and cortical resin of $P$. eldarica; the needles were also characterised by high amounts of $\beta$ pinene, while $\delta$ - 3 carene and limonene were found in high concentration in the cortex (Tab. 1).

Large variations in the amount of all monoterpenes were observed among the three different species. In particular, needles of $P$. halepensis showed a higher content of sabinene and myrcene than the other two 
foliar tissue
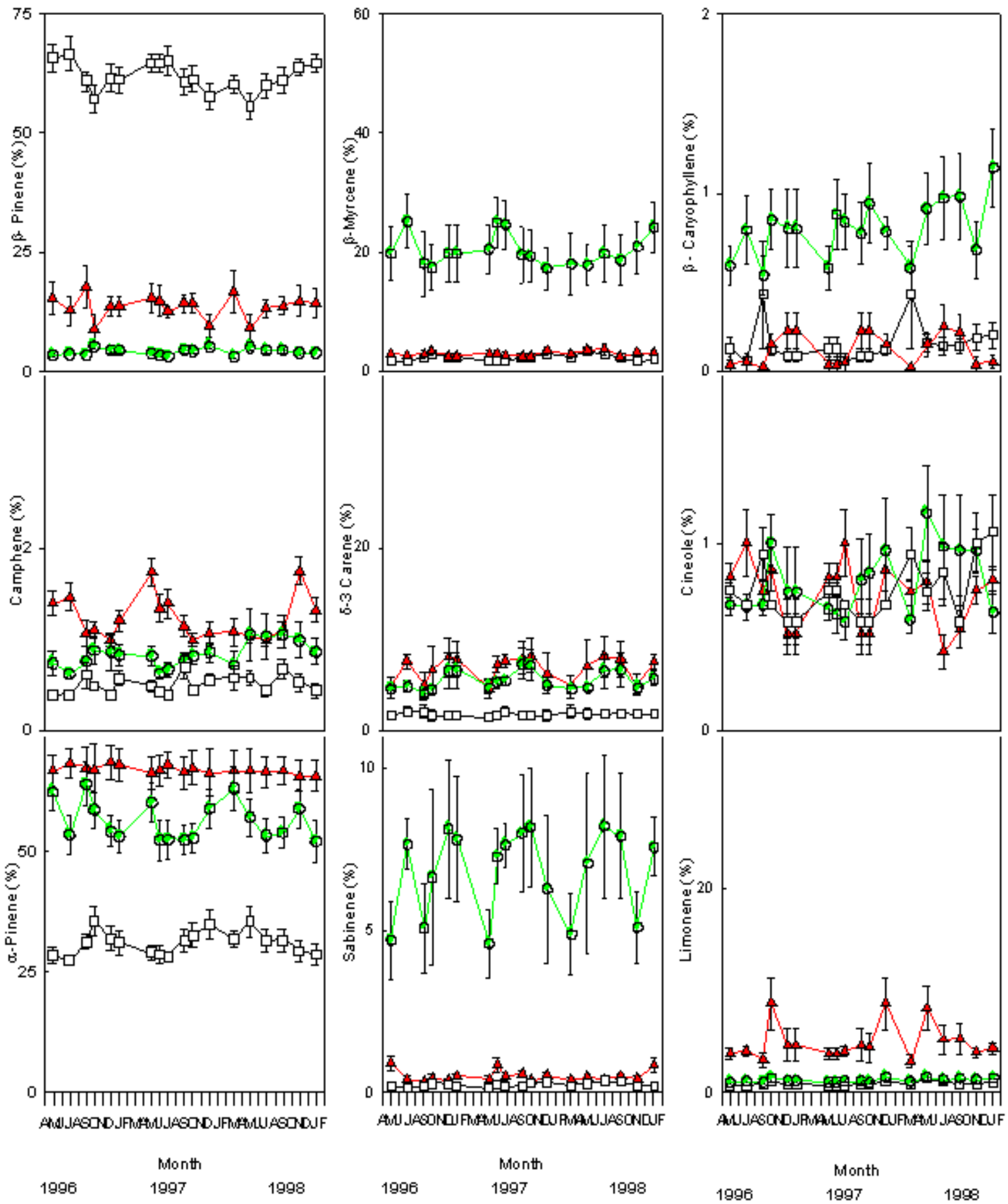

$$
\begin{aligned}
& \longrightarrow \text { P. brutia } \\
& \triangle \text { P. eldarica } \\
& \multimap \text { P. halepensis }
\end{aligned}
$$

Fig. 2 - Changes in the relative percentage of various monoterpenes detected in foliar tissues of $P$. halepensis, $P$. brutia and $P$. eldarica grown in an experimental plantation nearby Firenze, during the course of seasons and years. Data are the means \pm SE. Species are referred to by symbols in the legend. 


\section{cortical tissue}
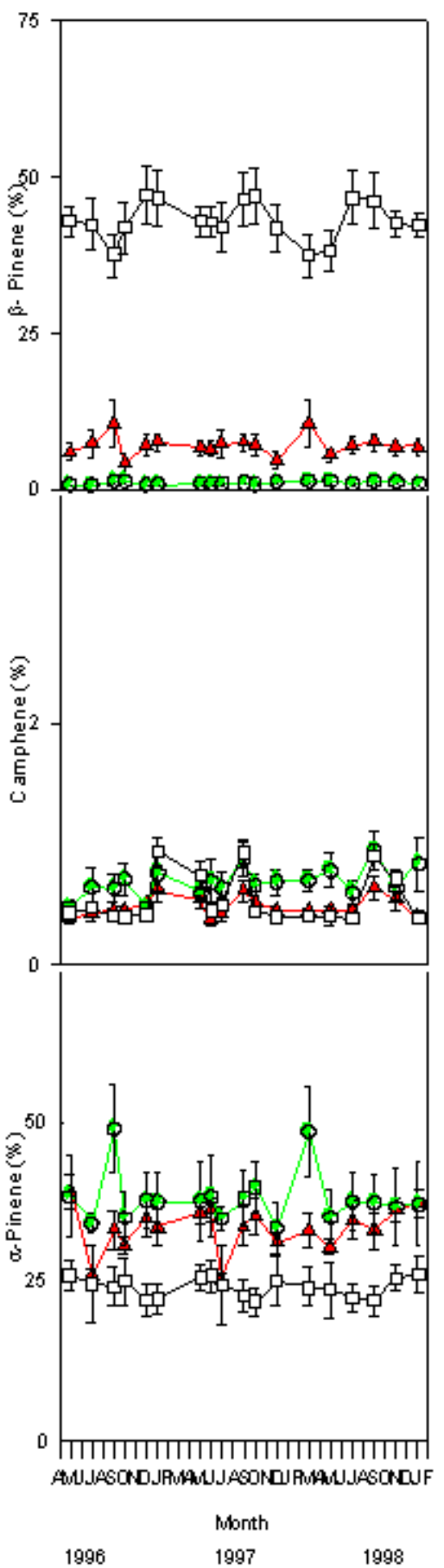

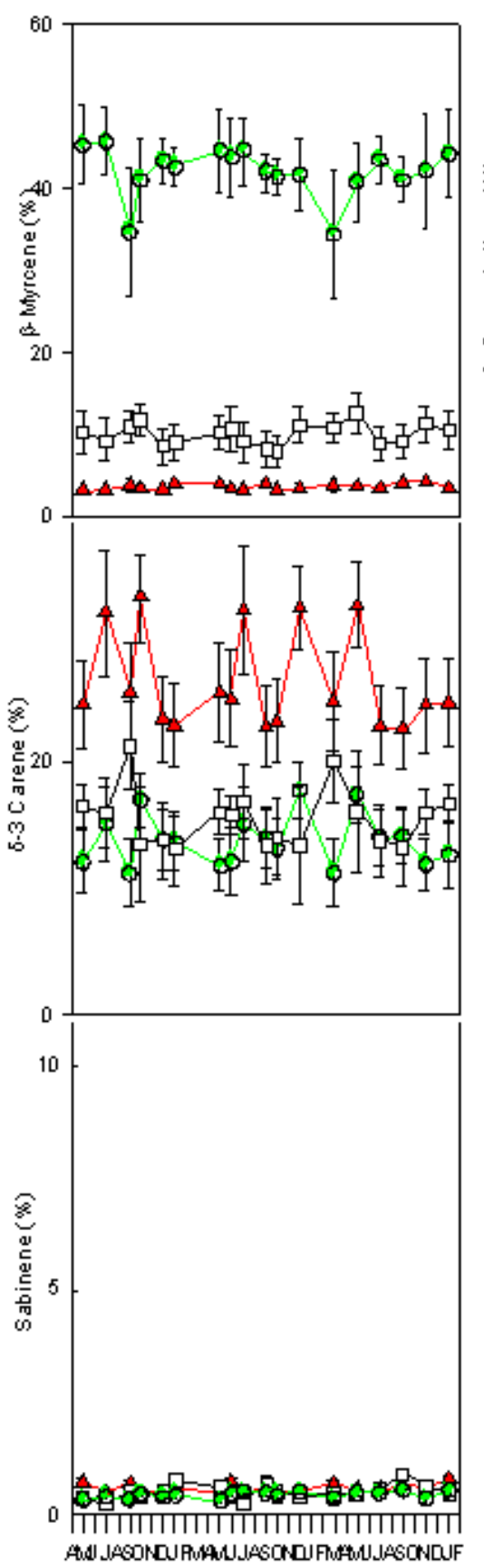

Month

1997

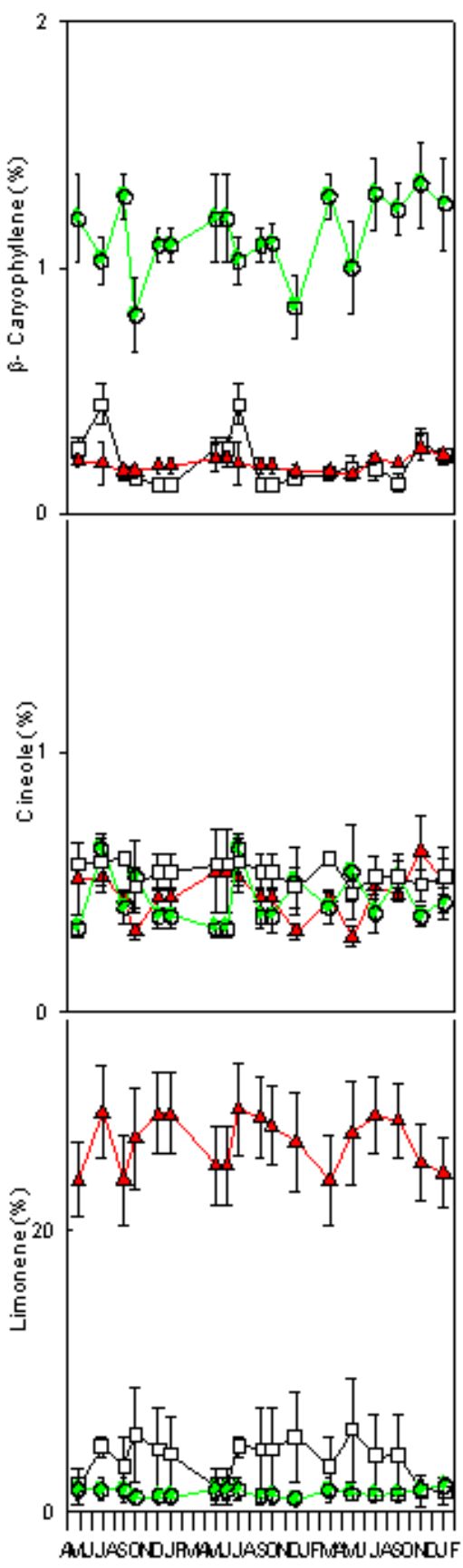

Month

1997 1998

Fig. 3 - Changes in the relative percentage of various monoterpenes detected in cortical tissues of $P$. halepensis, $P$. brutia and $P$. eldarica grown in an experimental plantation nearby Firenze, during the course of seasons and years. Data are the means \pm SE. Species are referred to by symbols in the legend. 
Tab. 1 - Mean terpene contents (percent \pm SE) in Pinus halepensis Mill., Pinus brutia Ten. and Pinus eldarica Medw.

\begin{tabular}{|c|c|c|c|c|c|c|c|c|c|c|}
\hline \multicolumn{2}{|c|}{ Source of variation } & \multirow{2}{*}{$\frac{\alpha \text {-pinene }}{56.13}$} & \multirow{2}{*}{$\begin{array}{c}\text { camphene } \\
0.83\end{array}$} & \multirow{2}{*}{$\begin{array}{c}\beta \text {-pinene } \\
4.03\end{array}$} & \multirow{2}{*}{$\begin{array}{c}\text { sabinene } \\
6.81\end{array}$} & \multirow{2}{*}{$\begin{array}{c}\delta \text {-3carene } \\
5.58\end{array}$} & \multirow{2}{*}{$\begin{array}{c}\text { myrcene } \\
20.43\end{array}$} & \multirow{2}{*}{$\begin{array}{c}\text { limonene } \\
1.18\end{array}$} & \multirow{2}{*}{$\begin{array}{c}\text { cineole } \\
0.77\end{array}$} & \multirow{2}{*}{$\begin{array}{c}\begin{array}{c}\beta \text {-caryo- } \\
\text { phyllene }\end{array} \\
0.79\end{array}$} \\
\hline Pinus halepensis & $\%$ & & & & & & & & & \\
\hline & SE & 0.92 & 0.03 & 0.12 & 0.38 & 0.30 & 1.04 & 0.05 & 0.04 & 0.04 \\
\hline \multirow[t]{2}{*}{ Pinus brutia } & $\%$ & 31.08 & 0.51 & 61.73 & 0.24 & 1.81 & 2.32 & 0.85 & 0.73 & 0.16 \\
\hline & SE & 0.54 & 0.02 & 0.58 & 0.01 & 0.10 & 0.10 & 0.03 & 0.03 & 0.03 \\
\hline \multirow[t]{2}{*}{ Pinus eldarica } & $\%$ & 66.82 & 1.24 & 13.82 & 0.53 & 6.88 & 2.95 & 4.91 & 0.72 & 0.12 \\
\hline & SE & 0.83 & 0.03 & 0.63 & 0.03 & 0.41 & 0.14 & 0.33 & 0.03 & 0.02 \\
\hline \multirow[t]{2}{*}{ Pinus halepensis } & $\%$ & 38.17 & 0.69 & 1.25 & 0.44 & 13.82 & 42.26 & 1.35 & 0.43 & 1.14 \\
\hline & SE & 1.19 & 0.03 & 0.04 & 0.02 & 0.56 & 1.06 & 0.14 & 0.02 & 0.03 \\
\hline \multirow[t]{2}{*}{ Pinus brutia } & $\%$ & 24.17 & 0.55 & 43.28 & 0.51 & 15.57 & 10.04 & 3.57 & 0.54 & 0.40 \\
\hline & SE & 0.75 & 0.02 & 0.85 & 0.03 & 0.67 & 0.52 & 0.52 & 0.01 & 0.19 \\
\hline \multirow[t]{2}{*}{ Pinus eldarica } & $\%$ & 33.37 & 0.48 & 7.03 & 0.58 & 26.33 & 3.78 & 26.29 & 0.46 & 0.21 \\
\hline & SE & 0.59 & 0.01 & 0.44 & 0.02 & 0.05 & 0.10 & 0.69 & 0.02 & 0.01 \\
\hline
\end{tabular}

Tab. 2 - Summary of repeated measures univariate analysis of variance of terpene content over the three consecutive years $(1996,1997,1998)$ in Pinus halepensis Mill., Pinus brutia Ten. and Pinus eldarica Medw. * = Significant at $\alpha<0.05$; ns $=$ not significant.

\begin{tabular}{ccccccccc}
\hline \multicolumn{8}{c}{ Terpene } \\
\hline$\alpha$-pinene & $\begin{array}{c}\text { cam- } \\
\text { phene }\end{array}$ & $\beta$-pinene sabinene & $\begin{array}{c}\delta \text {-3 } \\
\text { carene }\end{array}$ & myrcene & $\begin{array}{c}\text { limo- } \\
\text { nene }\end{array}$ & cineole & $\begin{array}{c}\beta \text {-caryo- } \\
\text { phyllene }\end{array}$ \\
\hline $\mathrm{ns}$ & $\mathrm{ns}$ & $\mathrm{ns}$ & $*$ & $\mathrm{~ns}$ & $\mathrm{~ns}$ & $\mathrm{~ns}$ & $\mathrm{~ns}$ & $\mathrm{~ns}$ \\
$\mathrm{~ns}$ & $\mathrm{~ns}$ & $\mathrm{~ns}$ & $\mathrm{~ns}$ & $\mathrm{~ns}$ & $\mathrm{~ns}$ & $\mathrm{~ns}$ & $\mathrm{~ns}$ & $\mathrm{~ns}$ \\
$\mathrm{~ns}$ & $\mathrm{~ns}$ & $\mathrm{~ns}$ & $\mathrm{~ns}$ & $\mathrm{~ns}$ & $\mathrm{~ns}$ & $\mathrm{~ns}$ & $\mathrm{~ns}$ & $\mathrm{~ns}$ \\
$\mathrm{~ns}$ & $*$ & $\mathrm{~ns}$ & $*$ & $\mathrm{~ns}$ & $\mathrm{~ns}$ & $\mathrm{~ns}$ & $\mathrm{~ns}$ & $*$ \\
$\mathrm{~ns}$ & $\mathrm{~ns}$ & $\mathrm{~ns}$ & $\mathrm{~ns}$ & $\mathrm{~ns}$ & $\mathrm{~ns}$ & $\mathrm{~ns}$ & $\mathrm{~ns}$ & $\mathrm{~ns}$ \\
$*$ & $*$ & $\mathrm{~ns}$ & $\mathrm{~ns}$ & $\mathrm{~ns}$ & $\mathrm{~ns}$ & $\mathrm{~ns}$ & $\mathrm{~ns}$ & $\mathrm{~ns}$ \\
\hline
\end{tabular}

pine species, while foliar tissue of $P$. brutia was characterised by a high proportion of $\beta$ pinene and low concentration of $\alpha$-pinene and $\delta-3$ carene; needles of $P$. eldarica contained much more limonene than $P$. halepensis and P. brutia. Considering the cortical tissue, $P$. halepensis showed the highest amount of myrcene and the lowest concentrations of $\beta$-pinene and limonene; the average for $\beta$-pinene was highest in P. brutia, while $P$. eldarica had a larger amount of limonene and $\delta-3$ carene (Tab. 1 ).

The proportion of monoterpenes differed considerably between cortical and foliar tissues of $P$. halepensis, $P$. brutia and $P$. eldarica. $\alpha$-Pinene, $\beta$-pinene, sabinene and the unknown compounds were present in higher concentrations in the foliar tissue than in the cortical tissue of $P$. halepensis, while the cortex showed higher relative proportions of $\delta-3$ carene and myrcene. Foliar tissues of $P$. brutia contained higher concentrations of $\alpha$ pinene and $\beta$-pinene, and lower amounts of $\delta$-3 carene, myrcene and limonene than cortical tissues. The relative abundance of four monoterpenes varied between tissues of $P$. eldarica; the needles were characterised by higher amount of $\alpha$-pinene and $\beta$-pinene, while $\delta$-3 carene and limonene were present in larger concentrations in the cortex (Tab. 1).

The mean proportions of constitutive foliar and cortical $\beta$-pinene, $\delta$ - 3 carene, myrcene, limonene, cineole and the unknown compounds did not vary significantly from year to year (Tab. 2).

Generally, different sampling dates within the year appeared to have no effect on monoterpene quantities, except for: $\alpha$-pinene in cortical tissue samples collected from $P$. eldarica during years 1996 and 1997; camphene in cortical tissue samples collected from P. brutia during the years 1997 and 1998; camphene in needles of $P$. eldarica sampled during years 1997 and 1998; sabinene in foliar tissue samples collected from P. halepensis during 1997; sabinene in cortical samples of P. brutia in 1997 and 1998; cineole detected in needles of $P$. eldarica collected in 1998; the unknown com- pound in cortex of $P$. halepensis in 1996; $\beta$ caryophyllene in cortical tissue samples of $P$. halepensis in 1996, and P. brutia during 1996 and 1997 (Tab. 3). $t$-Test analysis showed very few significant variations in the proportion of single monoterpenes between pairs of sampling dates (Tab. 4).

Seasonal patterns of gas exchange and water potential

The seasonal course of temperature followed long-term averages for the area, with small deviations amongst the three years. The beginning of summer 1998 was relatively drier than other years, while early winter relatively colder.

Seasonal trends of water potential reflected rainfall and temperature patterns (Fig. 4). In early spring, predawn water potential was relatively high, always above $-1 \mathrm{MPa}$ regardless of the species. Later in the season water potential began to decline owing to the lack of rainfall and reached a minimum in midsummer. After late-summer and fall rainfall, predawn water potential recovered to prestress values. Drought was increasingly pronounced from 1996 to 1998. Species differences were evident during peak water stress. In summer 1996, predawn water potential values were higher in P. brutia (-1.3 MPa) than in the other two species $(-1.8 \mathrm{MPa})$, but in summer 1997 this trend was reversed, $P$. eldarica showing the highest values $(-1.5$ $\mathrm{MPa}), P$. halepensis intermediate values $(-1.9 \mathrm{MPa})$ and $P$. brutia the lowest values (-2.4 MPa); again, summer 1998 P. brutia the lowest values $(-2.5 \mathrm{MPa})$, and $P$. halepensis and $P$. eldarica similar values $(-2.1 \mathrm{MPa})$.

Midday stomatal conductance followed water potential trends, except during the 
Tab. 3 - Summary of repeated measures univariate analysis of variance of terpene content within each year in Pinus halepensis Mill., Pinus brutia Ten. and Pinus eldarica Medw. * = Significant differences at the 5\% probability level; ns = not significant

\begin{tabular}{|c|c|c|c|c|c|c|c|c|c|c|c|}
\hline Year & Species & Tissue & $\alpha$-pinene & $\begin{array}{l}\text { cam- } \\
\text { phene }\end{array}$ & $\beta$-pinene & sabinene & $\begin{array}{c}\delta-3 \\
\text { carene }\end{array}$ & myrcene & limonene & cineole & $\begin{array}{l}\beta \text {-caryo- } \\
\text { phyllene }\end{array}$ \\
\hline \multirow{6}{*}{1996} & \multirow{2}{*}{ Pinus halepensis } & Foliar & $\mathrm{ns}$ & ns & ns & ns & ns & ns & ns & ns & ns \\
\hline & & Cortical & ns & ns & ns & ns & ns & $\mathrm{ns}$ & ns & ns & $*$ \\
\hline & \multirow{2}{*}{ Pinus brutia } & Foliar & ns & ns & ns & ns & ns & ns & ns & ns & ns \\
\hline & & Cortical & ns & ns & ns & ns & ns & ns & ns & ns & $*$ \\
\hline & \multirow{2}{*}{ Pinus eldarica } & Foliar & ns & ns & ns & ns & ns & ns & $\mathrm{ns}$ & $\mathrm{ns}$ & $\mathrm{ns}$ \\
\hline & & Cortical & $*$ & ns & ns & ns & $\mathrm{ns}$ & ns & ns & ns & ns \\
\hline \multirow{6}{*}{1997} & \multirow{2}{*}{ Pinus halepensis } & Foliar & ns & ns & ns & $*$ & ns & ns & ns & ns & ns \\
\hline & & Cortical & ns & ns & ns & ns & ns & ns & ns & ns & ns \\
\hline & \multirow{2}{*}{ Pinus brutia } & Foliar & ns & ns & ns & ns & ns & ns & ns & ns & ns \\
\hline & & Cortical & ns & $*$ & ns & $*$ & ns & ns & ns & ns & $*$ \\
\hline & \multirow{2}{*}{ Pinus eldarica } & Foliar & ns & $*$ & ns & ns & ns & ns & ns & ns & ns \\
\hline & & Cortical & $*$ & ns & ns & ns & ns & ns & ns & $\mathrm{ns}$ & $\mathrm{ns}$ \\
\hline \multirow{6}{*}{1998} & \multirow{2}{*}{ Pinus halepensis } & Foliar & $\mathrm{ns}$ & ns & ns & $\mathrm{ns}$ & ns & ns & ns & ns & ns \\
\hline & & Cortical & ns & ns & ns & ns & ns & ns & $\mathrm{ns}$ & ns & $\mathrm{ns}$ \\
\hline & \multirow{2}{*}{ Pinus brutia } & Foliar & ns & ns & ns & ns & ns & ns & ns & ns & ns \\
\hline & & Cortical & ns & $*$ & ns & $*$ & ns & ns & ns & ns & ns \\
\hline & \multirow{2}{*}{ Pinus eldarica } & Foliar & ns & $*$ & ns & ns & ns & ns & ns & $*$ & ns \\
\hline & & Cortical & $\mathrm{ns}$ & $\mathrm{ns}$ & ns & $\mathrm{ns}$ & $\mathrm{ns}$ & $\mathrm{ns}$ & ns & ns & ns \\
\hline
\end{tabular}

Tab. 4 - Comparison between pairs of sampling dates within each year by $t$-test analysis. Only significant differences in monoterpene variables are demonstrated. Ph-F: Pinus halepensis- Foliar tissue; Ph-C: Pinus halepensis- Cortical tissue; Pb-F: Pinus brutia- Foliar tissue; Pb-C: Pinus brutia- Cortical tissue; Pe-F: Pinus eldarica- Foliar tissue; Pe-C: Pinus eldarica- Cortical tissue.

\begin{tabular}{|c|c|c|c|c|}
\hline Months & July & May & December & September \\
\hline \multirow[t]{8}{*}{ October } & camphene $\mathrm{Pb}-\mathrm{C}(1998)$ & camphene $\mathrm{Pb}-\mathrm{C}(1997)$ & camphene Pe-F (1998) & $\beta$-caryophillene $\mathrm{Ph}-\mathrm{C}$ (1996) \\
\hline & sabinene $\mathrm{Pb}-\mathrm{C}(1997)$ & $\beta$-caryophillene $\mathrm{Pb}-\mathrm{C}(1996)$ & camphene $\mathrm{Pb}-\mathrm{C}(1997)$ & \\
\hline & $\beta$-caryophillene $\mathrm{Pb}-\mathrm{C}(1996)$ & $\beta$-caryophillene $\mathrm{Pb}-\mathrm{C}(1997)$ & sabinene $\mathrm{Pb}-\mathrm{C}(1997)$ & \\
\hline & $\beta$-caryophillene $\mathrm{Pb}-\mathrm{C}(1997)$ & camphene Pe-F (1998) & camphene Pe-F (1998) & \\
\hline & camphene Pe-F (1998) & $\alpha$-pinene Pe-C (1996) & $\alpha$-pinene Pe-C (1996) & \\
\hline & cineole Pe-F (1998) & & & \\
\hline & $\alpha$-pinene Pe-C (1996) & & & \\
\hline & $\alpha$-pinene Pe-C (1997) & & & \\
\hline \multirow[t]{7}{*}{ September } & camphene $\mathrm{Pb}-\mathrm{C}(1997)$ & sabinene $\mathrm{Pb}-\mathrm{C}(1998)$ & & \\
\hline & camphene $\mathrm{Pb}-\mathrm{C}(1998)$ & $\beta$-caryophillene $\mathrm{Pb}-\mathrm{C}(1997)$ & camphene $\mathrm{Pb}-\mathrm{C}(1997)$ & \\
\hline & sabinene $\mathrm{Pb}-\mathrm{C}(1997)$ & camphene Pe-F (1997) & sabinene $\mathrm{Pb}-\mathrm{C}(1998)$ & \\
\hline & sabinene $\mathrm{Pb}-\mathrm{C}(1998)$ & & & \\
\hline & $\beta$-caryophillene $\mathrm{Pb}-\mathrm{C}(1996)$ & & & \\
\hline & $\beta$-caryophillene $\mathrm{Pb}-\mathrm{C}(1997)$ & & & \\
\hline & cineole Pe-F (1998) & & & \\
\hline \multirow[t]{7}{*}{ December } & $\beta$-caryophillene $\mathrm{Pb}-\mathrm{C}(1996)$ & $\beta$-caryophillene $\mathrm{Pb}-\mathrm{C}(1996)$ & & \\
\hline & $\beta$-caryophillene $\mathrm{Pb}-\mathrm{C}(1997)$ & $\beta$-caryophillene $\mathrm{Pb}-\mathrm{C}(1997)$ & & \\
\hline & cineole Pe-F (1998) & camphene Pe-F (1997) & & \\
\hline & $\alpha$-pinene Pe-C (1996) & & & \\
\hline & $\alpha$-pinene Pe-C (1996) & & & \\
\hline & sabinene $\mathrm{Pb}-\mathrm{C}(1997)$ & & & \\
\hline & $\alpha$-pinene Pe-C (1996) & & & \\
\hline \multirow[t]{2}{*}{ May } & camphene Pe-F (1997) & & & \\
\hline & cineole Pe-F (1998) & & & \\
\hline
\end{tabular}


Fig. 4 - Seasonal course of net photosynthesis, needle conductance and predawn water potential in trees of $P$. halepensis, P. brutia and $P$. eldarica grown in an experimental plantation nearby Firenze (Italy). Data are the means \pm SE. An asterisk indicates significant $(\mathrm{P}<0.05)$ differences amongst the three species in that date. Species are referred to by symbols in the legend.

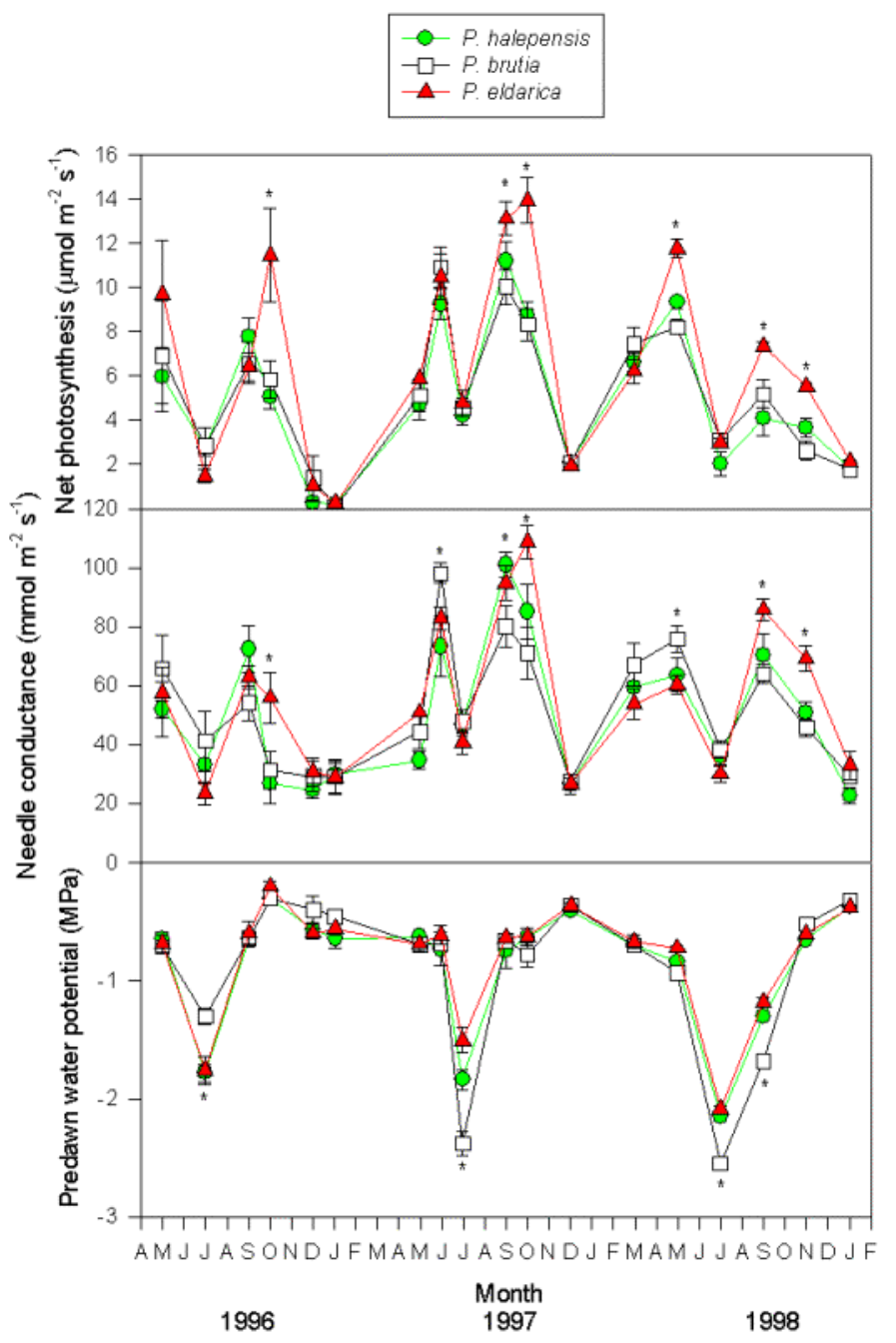

conductance appeared to be linearly related (Fig. 5). Differences in slope, representing overall intrinsic leaf water use efficiency, between species were not consistent, despite a tendency for a steeper relationship in $P$. eldarica compared to the other two species was evident; the intercept of the regressions differed between $P$. eldarica and the other two species $(P<0.01)$.

\section{Discussion}

The general picture shows that there were no seasonal effects on monoterpene profiles, contrary to what was observed for ecophysiological parameters. Besides, although total quantity of monoterpenes can be influenced by $\mathrm{CO}_{2}$ supply, no detectable effects on the relative proportions of the constitutive mixture were observed during summer months, when water stress occurred. As chemotaxonomic studies on coniferous species demonstrated, the constitutive compositional profile of a mature organ remains little affected by abiotic factors and that profile can be used as a biochemical marker in forest genetics (Baradat et al. 1991, Hanover 1992).

The most frequent results of inheritance studies suggested mono and oligogenic control of several monoterpenes in different coniferous species and more recently molecular studies have reported many plant genes that encode enzymes involved in the biosynthesis of terpenes (Nishizawa et al. 1992, Plomion et al. 1996, Raguso \& Pichersky 1999, Shepherd et al. 1999, Fischer et al. 2001, Trapp \& Croteau 2001, Fäldt et al. 2003). Some seasonal changes have been winter when low temperatures strongly reduced stomatal aperture (Fig. 4). The highest values were observed in spring and fall months, particularly 1997 and 1998 (80-100 $\mu \mathrm{mol} \mathrm{m} \mathrm{m}^{-2} \mathrm{~s}^{-1}$ ). Summer and winter minimum did not differ strongly amongst years, and stomatal functionality was never completely impaired (minimum $20 \mu \mathrm{mol} \mathrm{m} \mathrm{m}^{-2}$ ). Differences between species were not always consistent, but generally, P. brutia showed relatively higher values of stomatal conductance during spring, while $P$. eldarica had relatively higher values during fall, $P$. halepensis being in between the other two species. Similarly, photosynthetic rates showed maximum values in spring and fall $(8-10 \mu \mathrm{mol} \mathrm{m}$ $\mathrm{s}^{-1}$ ) and minimum values in summer and winter (below $4 \mu \mathrm{mol} \mathrm{m}^{-2} \mathrm{~s}^{-1}$ ), with $P$. eldarica rates higher than rates of the other two species in fall (up to $14 \mu \mathrm{mol} \mathrm{m} \mathrm{m}^{-2}$ - Fig. 4). Particularly low values (below $2 \mu \mathrm{mol} \mathrm{m} \mathrm{s}^{-2}$ ${ }^{1}$ ), regardless of species, were observed during winter 1996/97, coinciding with lowest temperatures recorded in the study period. Summer minimum was higher in 1997 and 1998 despite more pronounced drought than in 1996. Net photosynthesis and stomatal

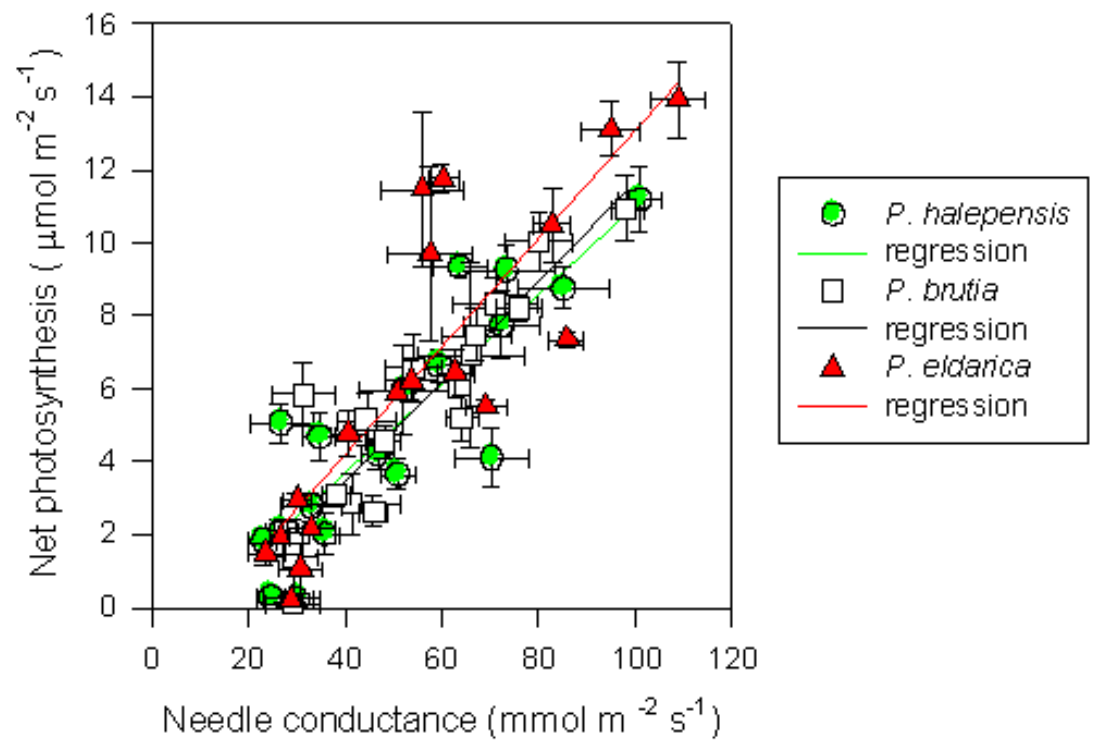

Fig. 5 - Linear relationship between net photosynthesis and needle conductance for $P$. halepensis, $P$. brutia and $P$. eldarica grown in an experimental plantation nearby Firenze (Italy). Data are the means \pm SE. Species are referred to by symbols in the legend. Parameters of regression equations $(P<0.0001), y=\mathrm{a}+\mathrm{b} x$, are the following: $P$. halepensis $\mathrm{a}=$ $-1.19, \mathrm{~b}=0.12, r^{2}=0.76 ;$ P. brutia $\mathrm{a}=-1.96, \mathrm{~b}=0.14, r^{2}=0.84 ;$ P. eldarica $\mathrm{a}=-1.77, \mathrm{~b}=$ $0.15, r^{2}=0.73$. 
confounded with epigenetic variations that occur in monoterpene proportion. Genes controlling changes in monoterpene expression, may be turned "on" or "off", or may be regulated during the early growth phases (Hanover 1992, Michelozzi et al. 1998). Studies showed that some changes in monoterpene composition have been related to seasonal attacks of herbivores (Harborne 1990). Terpenoid is the most expensive biosynthesis of all secondary compounds (Langenheim 1994). Plants cannot maintain high levels of these defence substances in all the tissues and organs, and at any given time. Therefore, particular mixtures with high content of toxic terpenoids are accumulated in target tissues, as young foliage, which is generally more vulnerable than older leaves to herbivore attack and more important for the plant because photosynthetic rates are higher in young than in old leaves (Wahid et al. 1997). Differences in the relative proportions of monoterpenes can be also detected between the constitutive terpenoid-rich resin and the induced resin that is synthesised de novo in response to fungal invasion. Some studies showed that inoculation with fung vectored by bark beetles could induce accumulation in the concentration of monoterpenes that possess insecticidal and fungistatic properties (Klepzig et al. 1996, Popp et al. 1995a-b, Raffa \& Smalley 1995, Raffa 1991, Russell \& Berryman 1976). However, Squillace (1976), Baradat et al. (1991) and Hanover (1992) provided a comprehensive sampling procedure for terpene analyses in forest genetic studies.

In addition to the simple Mendelian inheritance, epistatic and pleiotropic interactions were determined in genetic variation of terpenes (Vernet et al. 1986, Croteau \& Gershenzon 1994, Vogel et al. 1996).Considerable variation was observed in the constitutive monoterpene composition between the different species. Particularly three monoterpenes appeared to be very useful as biochemical markers to characterize the Mediterranean pine species of group "halepensis":

1. a high proportion of $\beta$-myrcene occurred in P. halepensis;

2. a high percent of $\beta$-pinene was detected in $P$. brutia. These findings agree with previous data showing the utility of constitutive monoterpenoids as biochemical markers to characterize these pine species (Baradat et al. 1995, Schiller \& Grundwald 1987a, b), and to measure hybridization between $P$. brutia and $P$. halepensis. The artificial hybrid $P$. brutia $\times$ P. halepensis showed high proportion of both $\beta$-pinene and $\beta$-myrcene (Michelozzi et al. 1998). These results of cortical constitutive terpenes were supporting earlier data obtained from isoenzyme analysis (Schiller et al. 1986).

3. Limonene can be very useful to distin- guish $P$. eldarica from the other Mediterranean pine species of group "halepensis"; however a large variation for limonene content between cortical and foliar tissue of $P$. eldarica was detected.

Epigenetic variations, such as those related to different tissues within a tree, are important in terpene constituents. Other common sources of qualitative and quantitative variation in monoterpenes are those occurring between juvenile and adult plants and between juvenile and mature tissues (Hanover 1992)

Needle water potential and gas exchange parameters did not vary strongly among or within taxa, but changed markedly during the year, uncoupling from monoterpene patterns. These results are consistent with results of studies with other pine trees (e.g., Samuelson et al. 1992). Seasonal variations in gas exchange were probably correlated with many factors whose relative importance changed as the growing season progressed. These include factors that are difficult to assess, such as foliage development, foliage aging, carbon demand, and measured environmental factors such as water availability, temperature, vapour pressure deficit and light (Maier \& Teskey 1992).

A rapid response to drought was evident in the three species, leading to a concurrent decrease in water potential and stomatal conductance. A rather high threshold of predawn water potential for stomatal closure has been found in previous studies on $P$. halepensis (both trees and seedlings - Schiller \& Cohen 1995, Tognetti et al. 1997, Borghetti et al. 1998). Such a response to drought may be crucial under Mediterranean conditions to prevent severe tissue dehydration and foliage dieback (Borghetti et al. 1998). The three species, however, only reduced stomatal aperture in response to drought, which is consistent with the hypothesis that complete stomatal closure is not the optimal response to water stress and that limited embolism allows a maximization of gas exchange (Jones \& Sutherland 1991) and contributes to limit water use as soil water is exhausted (Borghetti et al. 1998). Indeed, partial cavitation of xylem tracheids may cause a localised release of tension in the surrounding xylem, making water at higher water potential becoming available (Dixon et al. 1984). Schiller \& Cohen (1995) showed that $P$. halepensis trees could use internally stored water when soil is drying. The response of plants to soil drying has been suggested to be mediated by chemical signals generated in the roots and transported via the xylem (e.g., Jackson et al. 1995) or/and may be the result of hydraulic signals sensed by guard cells (Saliendra et al. 1995).

Gas exchange promptly recovered after late summer and fall rainfall relieved trees of water stress, even in summers when water po- tential was low enough to cause consistent xylem embolism (Tognetti et al. 1997). Refilling of xylem embolism has been shown for $P$. halepensis trees subjected to artificial soil drying in the field (Borghetti et al. 1998), though water potential was still negative. Despite drought was increasingly stronger during the three summer seasons studied, as shown by progressively lower water potential, gas exchange was rather stable or even higher during summer characterized by smaller amount of precipitation respect to mild summers. Seiler \& Johnson (1985) found that after subjecting Pinus taeda L. seedlings to drought, they maintained higher rates of net photosynthesis as needle water potential declined in a subsequent drying cycle. This response may have been partly the result of osmotic adjustment. Tognetti et al. (1997) found that drought-stressed $P$. halepensis seedlings had significantly reduced osmotic potential at turgor loss point with respect to unstressed controls. Gas exchanges, particularly photosynthesis, were low during winter months, suggesting that metabolism of these species is very sensitive to low temperatures. $P$. eldarica showed a delay in reducing photosynthesis in late fall with respect to $P$. halepensis and P. brutia, and also showed higher stomatal conductance in the same period. $P$. brutia stomatal conductance during the spring was higher than in the other two species. Seasonal differences in photosynthetic rate may be critical in accounting for genetic differences in productivity. For temperate conifers, differences in the depression of photosynthesis that accompany bud dormancy are often especially important (Teskey et al. 1987).

$P$. brutia appeared to be relatively more sensitive than $P$. eldarica and $P$. halepensis to increasing drought conditions from summer 1996 to summer 1998, resulting in lower water potential and lower gas exchange after recovery from water stress. A stronger reduction of soil-to-leaf hydraulic conductance in P. brutia may have been caused by preferential (compared to the other two species) cavitation in water conducting tracheids (Tognetti et al. 1997). Differences in gas exchange and water potential amongst the three species may be related to the natural distribution of these species (Weinstein 1989).

The linear relationship between stomatal conductance and net photosynthesis observed for $P$. halepensis, $P$. eldarica and $P$. brutia has been demonstrated for other pine species (e.g., Teskey et al. 1986). This may have some practical applications, since monitoring stomatal conductance may indirectly evaluate photosynthetic capacity ane be useful in genetic selection (Bennett \& Rook 1978). Despite the stomata are closely coupled to the photosynthetic system, the limitation imposed by the stomata on the rate 
of diffusion of carbon dioxide through them in pine trees is small (e.g., Teskey et al. 1986). The three species showed weak separation in the relationship between photosynthetic rate and stomatal conductance, which may reflect small differences in leaf water use efficiency (slope of regressions). The very low values of photosynthesis when needle conductance was still noticeable may indicate photochemical inhibition superimposing to stomatal constraints, particularly during winter (low temperatures).

In conclusion, our data show that constitutive monoterpene profiles remain constant during different months and years and do not seem to be affected by abiotic factors, as it is the case for ecophysiological parameters. In agreement with data in literature, $\beta$-pinene, $\beta$-myrcene and limonene are confirmed to be very useful biochemical markers for characterization of Mediterranean pine species of the group "halepensis". However, segregation and molecular analysis will be indispensable in order to provide the most-detailed understanding of monoterpene genetics in the contest of epistatic, pleiotropic interactions and Mendelian relationships. In the perspective to use hybrids of these pines (e.g., P. halepensis $\times$ P. brutia) combining high drought resistance, capability to grow on calcareous substrates, high quality of resin and yield ( $P$. halepensis), with high timber quality $(P$. brutia) for successful afforestation, it may be useful to relate physiological traits for resistance to environmental stresses and oleoresin terpene analysis. Variations in monoterpene profiles and ecophysiological responses to water stress also offer the opportunity to select chemotypes less susceptible to pest, diseases and drought.

\section{Acknowledgements}

Work on pine species of group "halepensis" was supported in part by PROJECT FAIR1-CT95-0097 from the EUROPEAN COMMUNITY.

\section{References}

Baradat P, Marpeau A, Walter J (1991). Terpene markers. In: Genetic variation in European populations of forest trees (Muller-Starck G, Ziehe M eds). Sauerlander's Verlag, Frankfurt am Main, pp. 40-66.

Baradat P, Michelozzi M, Tognetti R, Khouja ML, Khaldi A (1995). Geographical variation in the terpene composition of Pinus halepensis Mill. In: Population genetics and genetic conservation of forest trees (Baradat Ph, Adams WT, MullerStarck G eds). SPB Academic Publishing, Amsterdam, pp. 141-158.

Bennett KJ, Rook DA (1978). Stomatal and mesophyll resistance in two clones of Pinus radiata D. Don known to differ in transpiration and survival rate. Australian Journal of Plant Physiology 5: 231-238.
Borghetti M, Cinnirella S, Magnani F, Saracino A (1998). Impact of long-term drought on xylem embolism and growth in Pinus halepensis Mill. Trees 12: 187-195.

Castell C, Terradas J (1994). Effects of water and nutrient availability on water relations, gas exchange and growth rate of mature plants and resprouts of A. unedo L. Annals of Botany 73: 595602.

Cates RG (1996). The role of mixture and variation in the production of terpenoids in coniferinsect pathogen interactions. In: Phytochemical diversity and redundancy in ecological interactions (Romeo JT, Saunders JA, Barbosa P eds). Plenum Press, New York, pp. 179 - 216.

Coli WM, Hollingsworth CS, Hosmer TA (1997). Seasonal and vertical variation in activity of pear thrips (Thysanoptera: Thripidae) within stands of sugar maple. Canadian Journal of Research 27: 667-673.

Croteau R, Gershenzon J (1994). Genetic control of monoterpene bio-synthesis in mints (Mentha: Lamiaceae). In: Genetic engineering of plant secondary metabolism (Ellis B ed). Plenum Press, New York, pp. 193-229.

Dixon MA, Grace J, Tyree MT (1984). Concurrent measurements of stem density, leaf water potential and cavitation on a shoot of Thuja occidentalis. Plan, Cell and Environment 7: 615-618.

Fäldt J, Martin D, Miller B, Rawat S, Bohlmann J (2003). Traumatic resin defense in Norway spruce (Picea abies): Methyl jasmonate-induced terpene synthase gene expression, and cDNA cloning and functional characterization of $(+)$ 3carene synthase. Plant Molecular Biology 51: 119-133.

Fischer U, Vetter S, Novak J, Glasl S, Saukel J, Franz C (2001). Inheritance of the sesquiterpenes longipinenone and hydroxy-longi-pinenone within the Achillea millefolium complex (Compositae). Plant Breeding 120: 251-254.

Hanover JW (1992). Applications of terpene analysis in forest genetics. New Forests 6: 159-178.

Harborne JB (1990). Role of secondary metabolites in chemical defence mechanisms in plants. In: Bioactive compounds from plants (Chadwick DJ, Marsh J eds). John Wiley \& Sons, Chichester - New York - Singapore, pp. 126-134.

Klepzig KD, Smalley EB, Raffa KF (1996). Combined chemical defenses against an insect-fungal complex. Journal of Chemical Ecology 22: 13671388

Jackson GE, Irvine J, Grace J, Khalil AAM (1995). Abscisic-acid concentrations and fluxes in droughted conifer saplings. Plant, Cell and Environment 18: 1411-1418

Johnson JD (1984). A rapid technique for estimating total surface area of pine needles. Forest Science 30: 913-921

Jones HG, Sutherland RA (1991). Stomatal control of xylem embolism. Plant, Cell and Environment 14: 607-612.

Langenheim JH (1994). Higher plant terpenoids: a phytocentric overview of their ecological roles. Journal of Chemical Ecology 20: 1223-1280.

Maier CA, Teskey RO (1992). Internal and extern- al control of net photosynthesis and stomatal conductance of mature eastern white pine (Pinus strobus). Canadian Journal of Forest Research 22: 1387-1394.

Michelozzi M, Squillace AE, Vendramin GG (1990). Monoterpene in needles and cortex of an artificial $P$. brutia Ten. x $P$. halepensis Mill. hybrid. Journal of Genetic and Breeding 44: 241246.

Michelozzi M, White TL, Squillace AE, Lowe WJ (1995). Monoterpene composition and fusiform rust resistance in slash and loblolly pines. Canadian Journal of Forest Research 25: 193-197.

Michelozzi M, Radicati M, Properzi M (1998). Resin monoterpene composition of Mediterranean pines of group "halepensis". In: Proceeding of the International Conference "I Simposio de aprovechamiento de resinas naturals", Segovia 5-7 February 1998. Agrofitor, S.A. Segovia, Spain, pp. 67-76.

Michelozzi M (1999). Defensive roles of terpenoid mixtures in conifers. Acta Botanica Gallica 146: 73-84.

Nishizawa A, Honda G, Tabata M (1992). Genetic control of the enzymatic formation of cyclic monoterpenoids in Perilla frutescens. Phytochemistry 31:139-142.

Plomion C, Yani A, Marpeau A (1996). Genetic determinism of $\delta 3$-carene in maritime pine using RAPD markers. Genome 39: 1123-1127.

Popp MP, Johnson JD, Lesney M (1995a). Characterization of the induced response of slash pine to inoculation with bark beetle vectored fungi. Tree Physiology 15: 619-623

Popp MP, Johnson JD, Lesney M (1995b). Changes in ethylene production and monoterpene concentration in slash pine and loblolly pine following inoculation with bark beetle vectored fungi. Tree Physiology 15: 807-812

Potvin C, Lechowicz MJ, Tardif S (1990). The statistical analysis of ecophysiological response curves obtained from experiments involving repeated measures. Ecology 71: 1389-1400.

Raffa KF (1991). Induced defenses in conifer-bark beetle systems. In: Phytochemical induction by herbivores (Tallamy DW, Raupp MJ eds). Academic Press, New York,.pp. 245-276.

Raffa KF, Smalley EB (1995). Interaction of preattack and induced monoterpene concentrations in host conifer defense against bark beetle-fungal complexes. Oecologia 102: 285-295.

Raguso RA, Pichersky E (1999). A day in the life of a linalool molecule:chemical communication in a plant-pollinator system. 1. Linalool biosynthesis in flowering plants. Plant Species Biology 14: 95-120.

Ritchie GA, Hinckley TM (1975). The pressure chamber as an instrument for ecological research. Advances in Ecological Research 9: 165-254.

Russell CE, Berryman AA (1976). Host resistance to the fir engraver beetle1. Monoterpene composition of Abies grandis pitch blister and fungus-infected wounds. Canadian Journal of Botany 54: 14-18.

Saliendra NZ, Sperry JS, Comstock JP (1995). Influence of leaf water status on stomatal response 
to humidity, hydraulic conductance, and soil drought in Betula occidentalis. Planta 196: $357-$ 366.

Samuelson LJ, Seiler JR, Feret PP (1992). Gas exchange and canopy structure of 9-year-old loblolly pine, pitch pine and pitch $\mathrm{x}$ loblolly hybrids. Trees 6: 28-31.

Schiller G, Conkle MT, Grunwald C (1986). Local differentation among Mediterranean populations of Aleppo pine in their isoenzymes. Silvae Genetica 35: 11-19.

Schiller G, Grunwald C (1987a). Resin monoterpenes in range wide provenance trials of Pinus halepensis Mill. in Israel. Silvae Genetica 38 109-114.

Schiller G, Grunwald C (1987b). Cortex resin monoterpene composition in Pinus brutia provenances grown in Israel. Biochemical Systematics and Ecology 4: 389-394.

Schiller G, Cohen Y (1995). Water regime of a pine forest under a Mediterranean climate. Agricultural and Forest Meteorology 74: 181-193.

Seiler JR, Johnson JD (1985).Photosynthesis and transpiration of loblolly pine seedlings as influ- enced by moisture-stress conditioning. Forest Science 31: 742--749.

Shepherd M, Chaparro JX, Teasdale R (1999). Genetic mapping of monoterpene composition in an interspecific eucalypt hybrid. Theoretical and Applied Genetics 99: 1207-1215.

Squillace AE (1976). Analyses of monoterpenes of conifers by gas-liquid chromatography. In: Modern Methods in Forest Genetics (Miksche JP ed). Springer-Verlag, New York, pp. 120-157.

Teskey RO, Fites JA, Samuelson LJ, Bongarten BC (1986). Stomatal and non-stomatal limitation to net photosynthesis in Pinus taeda L. under different environmental conditions. Tree Physiology 2: 131-142.

Teskey RO, Bongarten BC, Cregg BM, Dougherty PM, Hennessey TC (1987) Physiology and genetics of tree growth response to moisture and temperature stress: an examination of the characteristics of loblolly pine (Pinus taeda L.). Tree Physiology 3: 41-61.

Tognetti R, Michelozzi M, Giovannelli A (1997). Geographical variation in water relations, hydraulic architecture and terpene composition of
Aleppo pine seedlings from Italian provenances. Tree Physiology 17: 241-250.

Trapp SC, Croteau RB (2001). Genomic organization of plant terpene synthases and molecular evolutionary implications. Genetics 158: 811832.

Vernet P, Gouyon PH, Valdeyron G (1986). Genetic control of the oil content in Thymus vulgaris $\mathrm{L}$ : a case of polymorphism in a biosyn-thetic chain. Genetica 69: 227-231.

Vogel BS, Wildung MR, Vogel G, Croteau R (1996). Abietadiene Synthase from grand fir (Abies grandis). Journal. Biological Chemistry. 38: 23262-23268.

Wahid A, Rasul E, ur-Rehman Rao A, Iqbal RM (1997). Photosynthesis in leaf, stem, flower, and fruit. In: Handbook of photosynthesis (Pessarakli M, ed). Marcel Dekker, Inc. New York, Basel, Honk Kong, pp. 623-632.

Weinstein A (1989). Geographical variation and phenology of Pinus halepensis, P. brutia and P. eldarica in Israel. Forest Ecology and Management 27: 99-108. 